\title{
How does the different pre-hospital healthcare workers dispatch ambulances in the pre-hospital environment in Denmark
}

\author{
Lasse P Bentsen ${ }^{1,2}$ \\ From 6th Danish Emergency Medicine Conference \\ Odense, Denmark. 20-21 November 2014
}

\section{Background}

In Denmark, all ambulance transports are dispatched through the Acute Medical Coordination Centre (AMK). Even though this unit is the only way to request an ambulance, it is experienced by many Emergency Technicians EMTs that the visitation based on patient illness and injury differs widely. The visitation is performed either by an AMK visitation officer (AMK-VO), or a doctor that takes contact to AMK to get the ambulance dispatched. Correct dispatching of emergency services can be a complex affair because AMK cannot see the patients themselves.

\section{Methods}

Three different cases were presented for EMTs, paramedics, and visitation officers at AMK. Each was asked to assign what kind of dispatch level (A, B, or C, where A is the most urgent) they would assign to the patients current need. They were also asked what kind of treatment they think the patient would need from the ambulance and the need for a medical emergency care unit (MECU).

\section{Results}

We had 116 responses (43 assistant EMTs, 36 treating EMTs, 27 paramedics, and 10 AMK-VO's). There was no statistical difference in any of the cases regarding if the respondents would dispatch differently, $\mathrm{p}=0.4,0.2$ and 0.4 , respectively. AMK-VO's were more likely to anticipate the use of pharmacological intervention in case $2(\mathrm{p}<0.001)$ and the use of isotonic $\mathrm{NaCl}$ infusion in cases 2 and $3(\mathrm{p}<0.001)$ than other respondents.

Correspondence: lasse.p.bentsen@gmail.com

${ }^{1}$ University of Southern Denmark, Odense, Denmark

Full list of author information is available at the end of the article

\section{Conclusion}

Even though the results do not show statistically significant differences, a larger and more structured survey is needed, especially considering the relatively small number of respondents in the AMK-VO group. It should also be noted that the cases were presented in written form, and that visitation normally is performed via phone contact. This could make a difference in how people would dispatch ambulances in reality. The anticipated treatment differed between the groups, when considering isotonic $\mathrm{NaCl}$ infusion and pharmacological intervention.

\section{Authors' details}

${ }^{1}$ University of Southern Denmark, Odense, Denmark. '2Falck Danmark A/S, Odense, Denmark.

Published: 16 July 2015

doi:10.1186/1757-7241-23-S1-A8

Cite this article as: Bentsen: How does the different pre-hospital healthcare workers dispatch ambulances in the pre-hospital environment in Denmark. Scandinavian Journal of Trauma, Resuscitation and Emergency Medicine 2015 23(Suppl 1):A8.

Submit your next manuscript to BioMed Central and take full advantage of:

- Convenient online submission

- Thorough peer review

- No space constraints or color figure charges

- Immediate publication on acceptance

- Inclusion in PubMed, CAS, Scopus and Google Scholar

- Research which is freely available for redistribution 